\title{
Private versus Social Costs in Bringing Suit
}

\section{Citation}

Louis Kaplow, Private versus Social Costs in Bringing Suit, 15(2) J. Legal Stud. 371 (1986).

\section{Published Version}

doi:10.1086/467817

\section{Permanent link}

http://nrs.harvard.edu/urn-3:HUL.InstRepos:10611787

\section{Terms of Use}

This article was downloaded from Harvard University's DASH repository, and is made available under the terms and conditions applicable to Other Posted Material, as set forth at http:// nrs.harvard.edu/urn-3:HUL.InstRepos:dash.current.terms-of-use\#LAA

\section{Share Your Story}

The Harvard community has made this article openly available.

Please share how this access benefits you. Submit a story.

\section{Accessibility}




\section{CHICAGO JOURNALS}

Private versus Social Costs in Bringing Suit

Author(s): Louis Kaplow

Source: The Journal of Legal Studies, Vol. 15, No. 2 (Jun., 1986), pp. 371-385

Published by: The University of Chicago Press

Stable URL: http://www.jstor.org/stable/724375

Accessed: 16/02/2010 19:21

Your use of the JSTOR archive indicates your acceptance of JSTOR's Terms and Conditions of Use, available at http://www.jstor.org/page/info/about/policies/terms.jsp. JSTOR's Terms and Conditions of Use provides, in part, that unless you have obtained prior permission, you may not download an entire issue of a journal or multiple copies of articles, and you may use content in the JSTOR archive only for your personal, non-commercial use.

Please contact the publisher regarding any further use of this work. Publisher contact information may be obtained at http://www.jstor.org/action/showPublisher?publisherCode=ucpress.

Each copy of any part of a JSTOR transmission must contain the same copyright notice that appears on the screen or printed page of such transmission.

JSTOR is a not-for-profit service that helps scholars, researchers, and students discover, use, and build upon a wide range of content in a trusted digital archive. We use information technology and tools to increase productivity and facilitate new forms of scholarship. For more information about JSTOR, please contact support@jstor.org.

The University of Chicago Press is collaborating with JSTOR to digitize, preserve and extend access to The Journal of Legal Studies. 


\title{
PRIVATE VERSUS SOCIAL COSTS IN BRINGING SUIT
}

\author{
LOUIS KAPLOW*
}

$\mathrm{T}$

HE enforcement of large portions of substantive law is through a legal system that relies on private parties to bring suit when such action is in their own best interests. Recent work has analyzed the serious deficiencies of this system of private enforcement that arise because the costs of operating the legal system create a divergence between actual private incentives to sue and those that would lead to socially optimal results. Steven Shavell reached two major conclusions in his analysis of this problem. ${ }^{1}$ First, he concluded that, in general, there is no systematic relationship between the social and the private benefits of bringing suit. ${ }^{2}$ Moreover, no obvious modification of the incentive structure governing private litigation can overcome this divergence. This far-reaching and important conclusion unfortunately has not received the attention it deserves. Second, Shavell noted that litigation contains a built-in externality in that the private costs of suit are generally less than the social costs, given that the plaintiff does not bear the defendant's or any public costs of suit.

* Assistant Professor, Harvard Law School, and Faculty Research Fellow, National Bureau of Economic Research. I wish to thank Lucian Bebchuk, Peter Menell, and Steven Shavell for helpful comments.

${ }^{1}$ Steven Shavell, The Social versus the Private Incentive to Bring Suit in a Costly Legal System, 11 J. Legal Stud. 333 (1982).

${ }^{2}$ In all the models examined here, private benefits are simply the damage award, whereas social benefits consist of the reduction in accident costs resulting from the deterrence effect of private suits. (Since deterrence increases care and thus decreases the probability of accidents, there are also fewer suits, leading to savings in litigation costs relative to what they would have been without the deterrent effect but assuming suits still were brought. This interaction makes it more difficult to make a clear conceptual distinction between social costs and benefits in Shavell's model.) Since the social benefits depend, among other things, on the costs and effectiveness of care-neither of which are part of the plaintiff's calculusprivate and social benefits would be in alignment only by chance. (It should be noted that, although the discussion proceeds using the rhetoric of accident law, the argument is quite general.)

[Journal of Legal Studies, vol. XV (June 1986)]

(C) 1986 by The University of Chicago. All rights reserved. 0047-2530/86/1502-0002\$01.50 
Peter Menell has criticized this latter conclusion on the ground "that the tendency toward excessive litigation implied by Shavell's analysis is overridden by the injuring party's ability to influence the likelihood of suit." ${ }^{3}$ In the context of his model, Menell proves that an efficient result is produced by the injurer's decision about the amount of damage to cause, which in turn affects whether it will be profitable for the injured party to sue. His analysis implicitly takes as given the legal rules-procedural and substantive-that govern liability and the assignment of the costs of litigation.

Menell's argument, although correct, in fact does not disturb Shavell's initial conclusions. Shavell's analysis of the divergence between private and social costs should be understood as questioning the efficiency of the panoply of legal rules governing liability. Notwithstanding Menell's demonstration, I will show that Shavell's argument is sufficient to establish the externality that litigation costs create. This conclusion suggests the possibility of remedial action through modifying the legal system that Menell implicitly takes as given.

Section I explains the intuition behind Menell's argument, which clarifies the nature of his implicit assumptions and thereby makes clear that his result is not in conflict with the claim that there exists a divergence between private and social costs in private litigation. The results are developed using numerical examples in Section II and are proved formally in Section III. ${ }^{4}$ Section IV offers some concluding remarks concerning the significance of these issues. Finally, the Appendix briefly demonstrates that Menell's efficiency result-in addition to being independent of the existence of a divergence between private and social costs-is, in part, a function of his model's assumption, standard in this literature, that litigation costs are independent of the amount at stake.

\section{The Relationship between Menell's and Shavell's Results}

Menell's approach involves examining the injurer's actions before harm is imposed. In particular, he focuses on the standard nuisance example in which the injurer's level of output determines the level of pollution and thus the level of damage to the victim. Menell begins by noting, as does Shavell, that the plaintiff will sue if and only if damages exceed the plain-

\footnotetext{
${ }^{3}$ Peter S. Menell, A Note on Private versus Social Incentives to Sue in a Costly Legal System, 12 J. Legal Stud. 41, 41 (1983); see also id. at 52 ("Thus the structure of the legal system implicitly internalizes the costs of litigation"').

${ }^{4}$ Sections I and II are self-contained so that readers who prefer the numerical examples to a more formal derivation can omit all but subsection D of Section III without a significant loss in understanding.
} 
tiff's litigation costs. ${ }^{5}$ Since the prospective defendant's ex ante behavior determines the level of damages, the critical insight is that the defendant can influence whether the plaintiff will sue. In particular, if the defendant reduces output so that damages are below the plaintiff's cost of suit, the plaintiff's incentive to sue will be eliminated.

More specifically, Menell correctly explains how the injurer's decision to increase output just beyond the suit threshold point will cost the injurer the sum of the plaintiff's and the defendant's litigation costs. The injurer obviously bears its own litigation costs if it crosses the suit preclusion threshold. Moreover, since the plaintiff will choose to sue precisely at the point where damages equal (or just exceed) its litigation costs, the defendant's damages will just equal the plaintiff's litigation costs when output is at the threshold point.

Menell's important observation is that this result is socially desirable. The social cost of the defendant's crossing the litigation threshold equals the sum of the parties' litigation costs, so crossing the threshold will be efficient if and only if the extra profit to be earned is sufficient to cover both sets of litigation costs. The injurer's extra profit from producing whatever level of output it selects beyond the threshold amount is net of the extra damages caused because they must be paid to the victim. Therefore, the injurer's overall decision between a low, suit-precluding output level and a higher output level that results in suit correctly balances all the costs and benefits. The injurer receives the additional profits from greater output, but it bears all the additional damages to the victim as well as the litigation costs of both parties (its own directly and the plaintiff's indirectly, as suggested by the preceding argument). Menell's conclusion, which he proves rigorously, is therefore that the injurer takes into account all litigation costs in making its decisions. ${ }^{6}$ On the basis of this result, he argues that there is no externality problem as Shavell suggested.

Within the confines of his model, Menell's argument is entirely correct until this final step. It is also important in its own right. The simple implication is that, if one sets aside the many other possible divergences

\footnotetext{
5 Issues of uncertainty, risk aversion, endogeneity of litigation costs, and other complications concerning lawsuits are ignored since they do not affect the basic argument or the response. In addition, I will follow Menell and Shavell in ignoring that the plaintiff might sue strategically - that is, even if damages do not exceed litigation costs, it might hope to extract a settlement by threatening the defendant with going forward despite the cost. All the assumptions used in Menell's argument will not be repeated here. Nor will any attempt be made to assess the general approach used by Menell or Shavell, including their definition of social welfare. This note is limited to examining which of their conclusions follow within their chosen frameworks and some of the differences between their models.

${ }^{6}$ As the Appendix demonstrates, this argument is subject to qualification if litigation costs are a function of the amount at stake.
} 
that could lead to second-best arguments for intervention, there is no justification for any action to alter injurers' strategic behavior in making lawsuits unprofitable for plaintiffs by reducing the level of damages. Given Shavell's arguments concerning divergences between private and social benefits and the possibility in more general models for the level of care taken to affect the probability of harm, however, there may indeed be reason to fear defendants' strategic behavior. Shavell demonstrated that suits will be too infrequent precisely when damages in a single case are too low to make it worthwhile for plaintiffs to sue. To the extent that injurers' ex ante strategic behavior can make this scenario more likely, there could be a problem with inefficient suit preclusion in addition to that noted in the Appendix.

Despite the accuracy of Menell's analysis, however, it does not follow from the social efficiency of the injurer's decision that there is no divergence between the private and the social costs of suit. It is still the case, as Shavell argued, that the plaintiff bears only its own legal costs; costs of the defendant constitute an externality. ${ }^{7}$ This externality is not addressed by Menell's analysis because of his implicit assumption that rules governing liability and litigation costs are not subject to modification. The private/social cost divergence itself is thus taken as a given.

The confusion arises because Menell does not address the question of whether there is a cost externality to the plaintiff's decision to bring suit. Instead, his investigation considers only whether there is an externality involved in the defendant's decision to preclude suit, taking as given any externality problem that may exist with the plaintiff's decision-making process. Shavell's demonstration of the private/social cost divergence leads, ceteris paribus, to an excessive incentive for the plaintiff to sue. It therefore follows that sometimes it might be efficient for society to adopt legal rules that prohibit or otherwise discourage suit, including the important possibility of substituting alternative modes of compensation or dispute resolution. Shavell's conclusion does not address the efficiency of injurers' actions that discourage suit, given the prevailing legal regime.

\section{Numerical Illustration of Results}

The examples that are necessary to prove the results can be derived from Table 1, which is a modified version of a similar set of illustrations used by Menell. This illustration is constructed so that the private and the social benefits of suit are equal, and it demonstrates that the divergence

\footnotetext{
${ }^{7}$ Of course, any public costs, for example, those of the court system, are also omitted from the plaintiff's decision calculus.
} 
TABLE 1

Illustration of Private/Social Cost Divergence in Absence of Private/Social Benefit Divergence

\begin{tabular}{ccccccc}
\hline \hline & & & & Net: Case A & Net: Case B \\
$x$ & $P^{\prime}$ & $D^{\prime}$ & $P$ & $D$ & $(a=15, b=30)$ & $\begin{array}{c}\text { (a }=b=30) \\
(6)\end{array}$ \\
\hline 1 & $11)$ & $(2)$ & $(3)$ & $(4)$ & 100 & 100 \\
2 & 100 & 1 & 100 & 1 & 100 & 190 \\
3 & 90 & 3 & 190 & 4 & 190 & 340 \\
4 & 70 & 6 & 270 & 10 & 270 & 320 \\
5 & 50 & 10 & 340 & 20 & 290 & 310 \\
6 & 20 & 390 & 40 & 320 & 260 \\
7 & 60 & 410 & 100 & 280 & \\
\hline
\end{tabular}

between private and social costs still exists and can lead to an inefficient outcome. The injurer's output level is indicated by $x$ in Table 1. Columns 1 and 2 indicate the marginal profits of the injurer $\left(P^{\prime}\right)$ and the marginal damages of the victim $\left(D^{\prime}\right)$ from each unit of output. Total profits $(P)$ and total damages $(D)$ appear next-for example, at $x=3, P=270=100+$ $90+80$. The litigation costs for the victim (plaintiff) and injurer (defendant) are, respectively, $a$ and $b$.

In case $\mathrm{A}$, litigation costs are assumed to be 15 for the plaintiff and 30 for the defendant. In case B, litigation costs are 30 for both parties, and the numbers in brackets are used instead. Columns 5 and 6 refer to the injurer's net profits in each instance. Net profits simply equal $P$ when the plaintiff does not sue, and they equal $P-D-b$ when the plaintiff finds it profitable to sue. For example, the 280 figure in column 5 equals $410-$ $100-30$.

In both cases, the socially optimal output (in the absence of litigation costs) is 5 units: up to that point, additional profits exceed further damages, whereas for the sixth unit of output, marginal damages (60 or 30) exceed marginal profits (20). The injurer's output would be 6 if suit were legally precluded: all units up to that point increase profits; the seventh unit decreases profits by 10 .

In case $\mathrm{A}$, the social benefit of suit is 40 (suit reduces output from 6 units to 5 , yielding a gain of $60-20$ ). The private benefit is also 40 since the injurer, in the presence of costly litigation as assumed in the example, will produce 5 units and thus cause damages of $40 .^{8}$

${ }^{8}$ The injurer will not find it profitable to preclude suit in this example, as is implied by the demonstration below that it would be socially undesirable (combined with the earlier explanation and later proof that the private and the social decision rules are the same). 
Although the private and the social benefits are equal, the private and the social costs are not. The private cost of litigation is 15 since the plaintiff bears only its own litigation costs. If the defendant's litigation costs were less than 25 , say, 15 , then the social costs of permitting use of the legal system would be 30 , which is less than the benefits of 40 , so the rule holding the injurer liable would be desirable. But in the posited example, the defendant's litigation costs are 30 , so the social cost is 45 , making liability undesirable. If suit were legally prohibited, 40 in social benefits would be sacrificed, but 45 in social costs would be saved. Therefore there is an excessive private incentive on the part of the plaintiff to litigate: its private costs are less than the benefits even though the social costs are greater. ${ }^{9}$

9 If the plaintiff, even though victorious (note this is stricter than the British rule), had to pay defendant's litigation costs, the result in this instance would be the unconstrained social optimum (that is, the optimum that would prevail in the absence of litigation costs). The equilibrium would be with an output of 5 , which would make it unprofitable for plaintiff to sue, and since there are no suits, no litigation costs would be incurred.

The conclusion that the unconstrained social optimum can be reached by such a costshifting rule does not generalize in a number of respects. First, in a model like Shavell's (see note 19 infra), so long as the probability of an accident is not reduced to zero and litigation costs are less than the loss resulting from an accident-neither condition being inconsistent with private/social convergence of costs and benefits-there will always be some litigation and thus some litigation costs (assuming a rule of strict liability). Second, in Menell's model, there can be an equilibrium without suit preclusion that involves no private/social divergences. Therefore, litigation costs are not necessarily avoided.

Third, in Menell's model, one cannot expect private/social benefit convergence throughout the relevant range. Private benefit equals damages, which are assumed to increase with output, which was a necessary condition for the optimality result above. Convergence would therefore require that the social benefits of suit also increase with output. That implies that profits are rising faster than damages, which cannot be true where marginal profit equals marginal damages or at higher levels of output. (Benefit convergence can exist in Table 1, case $\mathrm{A}$, at the unconstrained optimum output level only because the example is discrete rather than continuous.) More generally, benefit convergence is itself a happenstance event, so to expect that happenstance result to hold over a range of output and not just at any one point would be quite farfetched.

Finally, it is worth considering more generally the possible effects of making plaintiffs (even when victorious) bear defendants' litigation costs in Menell's model. There are three relevant situations. (1) Equilibrium before and after the change in cost rules is characterized by the plaintiff's bringing suit. In this instance, the defendant's output and social benefits are unchanged, and the same social costs are incurred. Fee shifting would thus be irrelevant. (2) The change converts an equilibrium involving suit to an injurer suit preclusion equilibrium, which is possible because higher plaintiff litigation costs imply that suit preclusion entails a higher, more profitable level of output. (This possibility argument also shows why a fourth case of moving from suit preclusion to equilibrium with suit is not a possible result.) This would entail a net social benefit. Menell's proof directly implies that the new equilibrium is more efficient than forcing litigation under the new circumstances, and forcing litigation in turn would entail the same output and litigation costs as in the initial situation (this is the argument in case 1); therefore, the result follows. (3) Equilibrium before and after the change involves suit preclusion. The change will increase equilibrium output, which will increase or decrease net benefits, depending on whether output is thereby closer to or farther from the 
Note that this inefficiency arises even though the injurer's decision not to preclude suit was efficient, taking as given the private/social cost divergence facing the plaintiff. Preclusion would require an output of 3: total damages of 10 are insufficient to induce the victim to bear litigation costs of 15 , but if output were increased to 4 , total damages would be 20 , and the victim would sue. The injurer's attempt to preclude suit would cost 90 in benefits $([70+50]-[10+20])$ - the effect of reducing output from 5 to 3-while saving only 45 in costs. Thus the injurer's behavior in failing to preclude suit, proved efficient by Menell, does not negate the possibility that it might be socially efficient to prohibit suit even when the injurer does not, which is one important implication of the private/social cost divergence argument. This conclusion is possible because the conditions guaranteeing the efficiency of the injurer's suit preclusion decision have no direct bearing on the conditions necessary for victims' private suits to be socially efficient.

To complete the analysis, consider case B in this illustration. Here the injurer will find it profitable to preclude suit by producing only 4 units. At that output, damages are only 20 , which does not fully cover the plaintiff's costs, assumed in this case to be 30 . The injurer sacrifices 50 in potential profits by not producing the fifth unit but saves 30 in litigation costs plus 40 in damages. Once again, as Menell proved for all such situations, this decision by the injurer is efficient, taking as given all the circumstances. The added unit of output has a social benefit of only 30 $(50-20)$, whereas litigation costs of 60 are avoided. But once again it would be efficient if the plaintiff were barred from suit. In that case, the injurer would produce 6 units rather than 4 , the increase in profit would be $70(50+20)$, and the increase in damages would be only $50(20+30)$. The reason there is a gain is that the plaintiff's incentive to sue results in excessively cautious behavior by the injurer. ${ }^{10}$

There still remains some ambiguity in interpreting this final case because, at the equilibrium output of 4 , the social benefits of suit are -20 , as indicated by the preceding calculation. Because the suit preclusion equilibrium entails no litigation costs, any inefficiency of the sort described here must be due to divergences in benefits. More generally, since private

unconstrained optimal output level. (Cases involving crossovers could only be resolved by direct measurement of profits and damages.) Of course, all these results are limited to the special assumptions of Menell's model, and different conclusions are quite possible in the general situation. See, for example, text following note 6 supra.

${ }^{10}$ By now it should be obvious that one could readily construct examples involving a suit preclusion equilibrium wherein the rule permitting the plaintiff to sue, even given the cost externality problem, would be desirable. Using the damage figures from case A would suffice. 
benefits are greater than zero at such an equilibrium, the assumption that social and private benefits are equal would imply positive social benefits at that equilibrium, so there could be no net gain from legally prohibiting suit. Finally, in that situation, no general conclusion can be made concerning the desirability of closing the divergence between private and social costs; such action would increase equilibrium output, which may or may not be desirable because equilibrium output initially may be below or above the unconstrained social optimum.

\section{Proof of Results}

\section{A. Preliminaries}

The derivations will use the following notation:

$$
\begin{aligned}
x & =\text { injurer's output } \\
P(x) & =\text { gross profits of injurer; at } x=0, P^{\prime}>0 ; P^{\prime \prime} \leq 0 ; \\
D(x) & =\text { gross damages of victim; } D^{\prime}>0 ; D^{\prime \prime}>0 ; \\
a & =\text { plaintiff's (victim's) litigation costs; and } \\
b & =\text { defendant's (injurer's) litigation costs. }
\end{aligned}
$$

If there is no liability, ${ }^{11}$ the injurer simply maximizes $P(x)$. This maximum occurs at $P^{\prime}(x)=0$. The "unconstrained" output level, $x_{u}$, will refer to this level of output. ${ }^{12}$

The victim's decision rule is to sue if and only if $D(x)>a .{ }^{13}$ Thus, if the liability rule permits suit, the injurer can preclude suit by choosing $x$ such that $D(x) \leq a$. Since profits increase with the level of output, the injurer will choose $x$ to guarantee precise equality. ${ }^{14}$ This level of output is denoted $x_{p}$ to refer to the suit preclusion outcome.

The injurer's other option is to set $x>x_{p}$ so that suit will result. In that case, the injurer would maximize $P(x)-D(x)-b$; the solution implies that $P^{\prime}(x)=D^{\prime}(x)$. The level of output that solves this equation will be

11 This case is meant to encompass any rule prohibiting suit, procedural or substantive. It is to be distinguished from the case in which the plaintiff will not sue even though there is liability-referred to here as the suit preclusion outcome.

${ }^{12}$ If $P^{\prime}>0$ for all $x, x_{u}$ would be infinite, in which case the social benefits of permitting suit would also be infinite so long as $D^{\prime}>P^{\prime}$ for some $x$; if not, there could not be any social benefits to suit. Neither case will be considered further.

${ }^{13}$ Here and elsewhere, arbitrary choices will be made for cases of precise indifference, that is, when $D(x)=a$. Such assumptions have no effect on the interpretation of the results.

${ }^{14}$ This is not precisely correct. Since $P^{\prime \prime} \leq 0$, it is possible that even the unconstrained output level would preclude suit, that is, $D\left(x_{u}\right)<a$, in which case the existence of liability has no constraining effect. Since liability is irrelevant in such instances, this case will not be considered further. 
referred to as $x^{*}$. Note that this is also the socially optimal level of output in the sense that it maximizes social welfare in the absence of litigation costs (and this output would result in the absence of litigation costs since no other imperfections are assumed to exist); it also is the optimum, given that litigation will result. The injurer will find the suit preclusion equilibrium maximizing if and only if

$$
P\left(x_{p}\right)>P\left(x^{*}\right)-D\left(x^{*}\right)-b .
$$

\section{B. Menell's Result}

Menell proves that, given that the legal rule permits suit, the injurer's decision whether to preclude suit is efficient. This result follows from a simple proof. A suit preclusion equilibrium is socially preferable to one involving suit if and only if

$$
P\left(x_{p}\right)-D\left(x_{p}\right)>P\left(x^{*}\right)-D\left(x^{*}\right)-a-b .
$$

The existence of a suit preclusion equilibrium implies that $D\left(x_{p}\right)=a$. Therefore (2) becomes

$$
P\left(x_{p}\right)-a>P\left(x^{*}\right)-D\left(x^{*}\right)-a-b,
$$

which is equivalent to

$$
P\left(x_{p}\right)>P\left(x^{*}\right)-D\left(x^{*}\right)-b .
$$

This statement of the rule for the social optimum is identical to (1), the statement of the injurer's decision rule, so the injurer's decision will be efficient. ${ }^{15}$

\section{Prohibiting Suit by Rule}

Consider first the case in which the equilibrium that is reached when suit is permitted involves suit. Then a rule prohibiting suit by the plaintiff (no matter what the level of damages sustained) would be desirable if and only if the net social benefits when output is unconstrained exceed the net social benefits when the injurer's output is constrained by suit; the latter total includes the costs of litigation, while the former does not. This can be expressed as

$$
P\left(x_{u}\right)-D\left(x_{u}\right)>P\left(x^{*}\right)-D\left(x^{*}\right)-a-b .
$$

15 The Appendix addresses how this conclusion must be modified if litigation costs are a function of the amount at stake.

Note that, if $x_{p}>x^{*}$, there will necessarily be a suit preclusion equilibrium since $P\left(x_{p}\right)>$ $P\left(x^{*}\right)$ (recalling the qualification in note 14 supra that $x_{u}>x_{p}$ ). Since the derivation in text does not assume that $x_{p}<x^{*}$-unlike the heuristic discussion and later examples-no separate proof for this case is required. 
It should be immediately apparent that inequality (4) failing to hold (that is, an equilibrium involving suit being more efficient than the injurer precluding suit by constraining its output) provides insufficient information to determine whether (5) holds, that is, whether a rule prohibiting suit would be desirable.

To focus on whether (5) could hold solely because of divergences between private and social litigation costs, ${ }^{16}$ one needs to add the further constraint that private and social benefits of suit are equal. ${ }^{17}$ (Note that "benefits" here refers only to effects on the injurer's behavior, not to the net benefits, which would subtract litigation costs. This terminology is employed specifically to isolate the litigation cost component of the problem.) This constraint is necessary because Shavell's first conclusion, unchallenged by Menell, indicates that private and social benefit divergences can independently be responsible for inefficient private litigation.

Private benefits (the plaintiff's benefits from bringing suit) are simply $D\left(x^{*}\right)$. Social benefits are defined as the difference between (i) the excess of profits over damages when suit is permitted and (ii) the excess when suit is prohibited. This equality of private and social benefits implies that

$$
D\left(x^{*}\right)=\left[P\left(x^{*}\right)-D\left(x^{*}\right)\right]-\left[P\left(x_{u}\right)-D\left(x_{u}\right)\right] .
$$

Rearranging terms yields

$$
\left[P\left(x_{u}\right)-D\left(x_{u}\right)\right]-\left[P\left(x^{*}\right)-D\left(x^{*}\right)\right]=-D\left(x^{*}\right) .
$$

Since this case involves suit, $D\left(x^{*}\right)>a$, so $-D\left(x^{*}\right)<-a$. Substituting in (7) gives

$$
\left[P\left(x_{u}\right)-D\left(x_{u}\right)\right]-\left[P\left(x^{*}\right)-D\left(x^{*}\right)\right]<-a .
$$

Rearranging terms in (5) in a parallel manner yields

$$
\left[P\left(x_{u}\right)-D\left(x_{u}\right)\right]-\left[P\left(x^{*}\right)-D\left(x^{*}\right)\right]>-a-b .
$$

${ }^{16}$ Menell's critique of Shavell is clearly directed at the cost divergence issue (see Menell, supra note 3, at $41 \& \mathrm{n} .2$ ); yet he does conclude that his model provides sufficient conditions for the "equivalence of the private and social incentives to sue when litigation is costly" (id. at 50-51; emphasis added), which, by definition, includes the issue of divergent benefits. This conclusion obviously fails since his analysis in no way addresses the issue of benefit divergence.

Menell similarly argues that, if the loser (which in his model is always the defendant) must bear all litigation costs (the British rule), the "[e]quivalence of the private and social incentives to sue also holds." Id. at 51 . He notes that, under this approach, the plaintiff will always sue (in his model). But this leads to a result equivalent to a forced suit equilibrium, which Menell earlier proved inferior to the suit preclusion equilibrium in those cases in which the injurer finds it profitable to select that result! Menell is correct in asserting here that "suit occurs only if it is socially desirable" (id. at 52) precisely because he once again is taking as given the rest of the system, which may give the plaintiff the wrong incentives.

17 An examination of Menell (id.) reveals that private and social benefits of suit are not equal in his examples or derivations. 
Condition (8) is clearly insufficient to guarantee that condition (9) failsthat is, that private suit should never be prohibited-unless $b=0$. But that, of course, is precisely the condition that there is no externality to the plaintiff's decision to sue. When $b>0$, it is possible for condition (9) to hold. ${ }^{18}$ To prove the matter formally, it suffices to offer numerical examples, each consistent with all prior constraints, providing different results concerning the desirability of a rule prohibiting suit. Sufficient examples have been presented in Section II.

Finally, consider the comparison in the case in which a rule permitting suit involves a suit preclusion equilibrium as a result of the injurer's finding it profit maximizing to constrain its output level sufficiently. In this case, a rule prohibiting suit would be desirable if and only if

$$
P\left(x_{u}\right)-D\left(x_{u}\right)>P\left(x_{p}\right)-D\left(x_{p}\right) .
$$

Once again, none of the prior qualifications suggests any necessary conclusion concerning the direction of this inequality. Proof through numerical examples has been presented in Section II. It should be noted, however, that in this instance it is not possible for a rule prohibiting suit to be desirable solely because of a divergence in costs rather than in benefits. The simple reason is that, in this equilibrium, no litigation costs are actually incurred, although their level does determine $x_{p}$ and thus affects whether liability is desirable. To demonstrate this, rearrange (10) as follows:

$$
\left[P\left(x_{u}\right)-D\left(x_{u}\right)\right]-\left[P\left(x_{p}\right)-D\left(x_{p}\right)\right]>0 .
$$

Then simply note that condition (8) - which is implied by the equality of private and social benefits (6)-is sufficient to rule out this possibility.

\section{Interpretation of Results}

The possibility that a rule prohibiting suit might be desirable in either instance is well in accord with intuition. When a liability rule results in suits (that is, when a suit preclusion equilibrium is not efficient, given that suit is legally permissible), it is possible that litigation costs will be substantial even though social benefits from suit are minimal. Low benefits result when suit has little effect on the injurer's behavior, as would be the case where the unconstrained level of output $\left(x_{u}\right)$ is not significantly greater than the optimal level $\left(x^{*}\right)$. The constraint that the private benefits equal the meager social benefits - an equality that would result only by sheer coincidence-is insufficient to rule out the undesirability of suit

\footnotetext{
18 Inspection of the additional constraint that condition (1) fails-because this case assumes that there is not a suit preclusion equilibrium-indicates that this possibility is still not eliminated, as the examples of Section II demonstrate.
} 
since the total social costs include not only the victim's litigation costs, which is all that it considers in deciding whether to sue, but the defendant's as well. Of course, the possibility of this result does not in itself indicate the practical significance of situations in which private litigation will thus prove to be inefficient.

When the use of a liability rule results in a suit preclusion equilibrium, there are no litigation costs, and thus it might appear that a rule forbidding suit offers no potential for further gain. This is not necessarily the case, however, because it is possible that the deterring effect of suit, resulting in decreased output ( $x_{p}$ rather than $x^{*}$ ) results in more of a social cost than the excessive output that would result if suit were no longer permitted $\left(x_{u}\right.$ rather than $\left.x^{*}\right)$. This result would occur when the possibility of suit deterred output substantially - as might be the case where the plaintiff's litigation costs were small but the defendant's were substantial-and when the absence of liability had only a modest effect in terms of excessive output. Again, this only demonstrates the possibility of this result without providing any indication of its likelihood.

\section{Conclusion}

The preceding analysis demonstrates that Menell came up with a different answer from Shavell because he asked a different question-focusing on the efficiency of the injurer's (prospective defendant's) ex ante behavior rather than on the efficiency of the victim's (plaintiff's) ex post behavior. Neither question, in the abstract, is the "right" one; both are relevant for different purposes. Thus the import of the argument here is that Shavell's original claim concerning the private/social cost divergence stands untouched. Menell's contribution has been to demonstrate an interesting but rather separate proposition concerning the efficiency of the injurer's strategic behavior.

It is also worth keeping in mind that any conclusions concerning the private/social cost divergence in terms of incentives to sue can be highly misleading when viewed in isolation because of the general divergence between private and social benefits. Shavell illustrated well how, a priori, the combination of both divergences could readily run in either direction, so no simple conclusions concerning, for example, appropriate fee shifting arrangements can be derived from this discussion. Along those lines, the reader should note that the result that it may be socially optimal to ban suits (change a rule to one of no liability) was shown to be possible but not necessarily likely.

It is worth noting that this existence result is not really new. For example, some of those advocating no-fault auto insurance (which includes 
a rule of no liability) argue in part that the social benefits of the liability system (in terms of deterrence) are likely to be small by comparison to the costs of operating that system. In addition, some of the arguments advanced in favor of workers' compensation or other quasi-strict liability schemes are motivated by similar concerns. More generally, it is important to emphasize that the references throughout the preceding discussion to the option of legally prohibiting suit can be misleading if not interpreted broadly, in that alternatives to litigation-including systems that incorporate direct regulation as one component-rather than a pure regime of no liability would often be the appropriate response. Taking such options into account increases the potential significance of the effects of litigation costs. For example, it might often be the case that a costly litigation system in its current form will be clearly superior to elimination of liability altogether (without providing any substitute) yet inferior to other systems that may sacrifice, for example, some of the incentive properties of a liability system in exchange for savings in other costs or for better achievement of other objectives.

Shavell and Menell have each offered different models ${ }^{19}$ and some different (although not necessarily inconsistent) conclusions concerning the incentive to sue when litigation is costly. Since the efficiency of the entire private law system-either by comparison to eliminating liability altogether or to other forms of social regulation-depends on the operation of the litigation system, which is the subject of these investigations, it is important that far greater attention be devoted to studying these issues.

\section{APPENDIX}

\section{RESULTS WHERE LITIGATION COSTS INCREASE WITH THE LEVEL OF DAMAGES}

The model presented in Section III as well as in the rest of the analysis in this note followed both Menell and Shavell in assuming that litigation costs, $a$ and $b$,

19 It should also be noted that Menell's model, which is used in this investigation, focuses on the activity level rather than on the level of care, the latter having been the focus of Shavell's inquiry. For a discussion of some of the differences between these issues, see Steven Shavell, Strict Liability versus Negligence, 9 J. Legal Stud. 1 (1980); Menell, supra note 3, at 49-50, 52. As Menell notes, the difference in examples has some relevance to the applicability of Menell's argument even if it were correct. In particular, Menell's effect results from the injurer's ex ante decision leading to a smaller magnitude of injury, whereas some types of care may decrease the probability of injury. Suit only arises in the event of harm, so greater care that affects only the probability would not enable the injurer to preclude suit in the manner suggested by Menell's examples. 
were constant. It might, however, be more realistic to assume that litigation costs increase with the amount at stake, which in this model is $D(x) .^{20}$

This modification of the original assumption, however, affects none of the analysis establishing the existence of a divergence between private and social costs in plaintiffs' decisions to bring suit since that result depended only on the fact that the plaintiff does not bear the total costs of litigation, whatever that total might be. It does, however, modify Menell's separate conclusion that the decision of injurers concerning whether to preclude suit is efficient, as will now be established.

\section{REvised MODEL}

If litigation costs increased with the stakes, the model in Section III could be modified simply by replacing $a$ and $b$ with $a(D(x))$ and $b(D(x))$, where $a(0)>0$, $0<a^{\prime}<1$, and likewise for $b$. (That is, litigation costs for any suit are strictly positive, and litigation costs increase with the stakes but do not increase faster than the stakes.) Then equations (1)-(4) would become:

$$
\begin{gathered}
P\left(x_{p}\right)>P\left(x^{*}\right)-D\left(x^{*}\right)-b\left(D\left(x^{*}\right)\right) \\
P\left(x_{p}\right)-D\left(x_{p}\right)>P\left(x^{*}\right)-D\left(x^{*}\right)-a\left(D\left(x^{*}\right)\right)-b\left(D\left(x^{*}\right)\right) \\
P\left(x_{p}\right)-a\left(D\left(x_{p}\right)\right)>P\left(x^{*}\right)-D\left(x^{*}\right)-a\left(D\left(x^{*}\right)\right)-b\left(D\left(x^{*}\right)\right) \\
P\left(x_{p}\right)>P\left(x^{*}\right)-D\left(x^{*}\right)-b\left(D\left(x^{*}\right)\right)-\left[a\left(D\left(x^{*}\right)\right)-a\left(D\left(x_{\mathrm{p}}\right)\right)\right] .
\end{gathered}
$$

Comparing equations $\left(4^{\prime}\right)$ and $\left(1^{\prime}\right)$ reveals that the social and the private decision rules are no longer identical. First, consider the case in which $x_{p}<x^{*}$, which implies that $a\left(D\left(x_{p}\right)\right)<a\left(D\left(x^{*}\right)\right)$, making the bracketed term in equation $\left(4^{\prime}\right)$ positive. This implies that the injurer does not fully internalize the victim's litigation costs. As reexamination of the earlier intuitive argument suggests, the injurer only internalizes the victim's litigation costs measured at the suit preclusion equilibrium, $a\left(D\left(x_{p}\right)\right)$. The increase in litigation costs beyond that point, $a\left(D\left(x^{*}\right)\right)-a\left(D\left(x_{p}\right)\right)$, is an externality, so it now becomes possible that the injurer will not preclude suit even if it is socially efficient.

In the case in which $x_{p}>x^{*}$, there is necessarily a suit preclusion equilibrium. In this instance, the internalized litigation costs of the plaintiff exceed those resulting when suit is brought: $a\left(D\left(x_{p}\right)\right)>a\left(D\left(x^{*}\right)\right)$. It is therefore possible for there to be a suit preclusion equilibrium that is inefficient.

\section{INTERPRETATION}

The conclusion is that variable litigation costs create some private/social cost divergence in injurers' decisions to preclude suit. The problem is that the injurer considers $a\left(D\left(x_{p}\right)\right)$-the victim's litigation costs corresponding to the damage level at the suit preclusion equilibrium-rather than $a\left(D\left(x^{*}\right)\right)$, the victim's litigation costs corresponding to the damage level that would prevail at the optimum output level, given suit. In Menell's model, since litigation costs were constant,

20 The intuition behind this new assumption is clear enough. The greater the stakes in litigation, the more each side should be prepared to spend in order to achieve the desired result. One would expect that a firm will spend more to bring or defend a $\$ 1,000,000$ suit than one involving only $\$ 1,000$ in damages, even if the legal and factual issues are otherwise identical. 
these two magnitudes were equal, so there was no private/social cost divergence in the injurer's decision to preclude suit.

Interpreting the second case-inefficient suit preclusion-illustrates how these modified results can be understood intuitively. Inefficient suit preclusion results in this model when a suit preclusion equilibrium entails high damages and, therefore, high litigation costs for the victim - sufficiently high to deter suit-even when suit would result in much lower damages-because of the ex ante effect on the injurer's behavior-and therefore much lower litigation costs. In this event, consider the effect of forcing victims to sue or, more plausibly, of inducing them to sue by subsidizing their litigation costs. The resulting ex ante effect on the injurer's behavior implies that both damages and actual litigation costs incurred (including the costs covered by the subsidy) would be low, resulting in substantial benefits from litigation at little cost. This result follows even though-since it is a suit preclusion equilibrium from which the analysis began - the plaintiff's actual litigation costs (before subsidy) exceed the damages inflicted (which created the necessity for considering subsidization in the first instance). ${ }^{21}$

21 The claim in the text that in this case $a\left(D\left(x^{*}\right)\right)>D\left(x^{*}\right)$ follows because $a^{\prime}<1$, combined with the assumption that $x_{p}>x^{*}$ and the definition of $x_{p}$, which requires that $a\left(D\left(x_{p}\right)\right)=D\left(x_{p}\right)$. 